\title{
Kombinasi Teknologi Aplikasi GPS Mobile dan Pemetaan SIG dalam Sistem Pemantauan Demam Berdarah (DBD)
}

\author{
Andhy Sulistyo*, Anton Yudhana, Sunardi, Resmi Aini \\ Program Studi Magister Teknik, Informatika \\ Universitas Ahmad Dahlan, Yogyakarta 55164 \\ *Andhysulistyo@gmail.com
}

\begin{abstract}
Abstrak-Kasus Demam Berdarah Dengue (DBD) di Indonesia masih menjadi masalah kesehatan yang besar sehingga diperlukan pemantauan terhadap penyebaran kasus DBD. Penelitian ini mengamati proses pemantauan breeding place penyebab DBD dengan aplikasi yang menggabungkan teknologi Global Positioning System (GPS) mobile dan pemetaan Sistem Informasi Geografis (SIG). Pemodelan SIG dilakukan untuk menghasilkan peta zona risiko insiden dengue. Tujuan penelitian ini adalah mendapatkan pola sebaran breeding place dan mengetahui faktor pendukung berkembang biaknya jentik nyamuk, khsusnya di wilayah Kabupaten Bantul. Studi dilaksanakan dengan menggunakan pemetaan, teknologi SIG dan teknik analisis statistik spasial. Populasi penelitian berada di wilayah Kabupaten Bantul. Sampel breeding place diambil secara acak menggunakan aplikasi GPS untuk mendapatkan titik koordinat yang tepat. Koordinat breeding place dijadikan sebagai variabel independen sedangkan variabel dependen adalah kepadatan permukiman, jarak dengan sungai, dan ketinggian tempat. Penelitian menunjukkan bahwa breeding place mempunyai nilai average nearest neighbor 0,690 dan nilai z-score-10,663. Tingkat kerawanan DBD di Kabupaten Bantul berdasarkan penyebaran breeding place dipengaruhi oleh kedekatan dengan sungai (66\%), kepadatan pemukiman (56\%), dan ketinggian wilayah (52\%). Disimpulkan bahwa breeding place di Kabupaten Bantul memiliki sifat berkerumun dan menunjukkan pola spasial yang clustered dengan tingkat kerawanan kasus DBD sebesar $64 \%$. Sungai mempunyai pengaruh terhadap keberadaan breeding place yaitu sebesar $66 \%$.
\end{abstract}

Kata kunci: demam berdarah, breeding place, GPS, SIG.

\section{Pendahuluan}

Indonesia sebagai negara berkembang masih mengalami banyak kasus demam berdarah dengue (DBD) dengan tingkat Kejadian Luar Biasa (KLB). Sejak adanya laporan pertama pada tahun 1968 di Surabaya, kasus DBD cenderung meningkat baik dalam jumlah maupun luas wilayah penyebaran [1]. Daerah Istimewa Yogyakarta merupakan daerah endemis DBD yang menduduki peringkat kelima secara nasional. Menurut data Dinas Kesehatan, Bantul mengalami 622 kasus DBD pada tahun 2014, kemudian meningkat menjadi 1441 kasus di tahun 2015, dan meningkat lagi di tahun 2016 menjadi 2442 kasus.

Benda atau tempat yang menjadi lokasi perkembangbiakan jentik nyamuk disebut breeding place. Di tempat inilah nyamuk berkembang biak dan jumlahnya semakin meningkat [2]. Keberadaan breeding place dapat menimbulkan risiko tiga kali lipat terhadap kejadian DBD [2]. Oleh karena itu, salah satu upaya pengendalian kasus DBD dilakukan dengan gerakan Pemberantasan Sarang Nyamuk (PSN) sebagaimana diatur dalam Peraturan Menteri Kesehatan Republik Indonesia Nomor 374/ MENKES/PER/III/2010 tentang Pengendalian Vektor penular (Aedes Aegypti) yang mengatur masalah manajemen pengendalian vektor secara umum [3].
Dalam upaya pemberantasan sarang nyamuk, pemerintah memerlukan bantuan dan partisipasi masyarakat. Anggota masyarakat dapat berperan sebagai "Juru Pemantau Jentik (Jumantik) Rumah Tangga" atau dalam program Satu Rumah Satu Jumantik. Peran Jumantik dapat diperkuat dengan penggunaan teknologi informasi dan komunikasi, sebagaimana yang diupayakan dalam penelitian ini. Perangkat smartphone yang tersebar luas di masyarakat berikut fasilitas GPS yang ada dalam perangkat itu digunakan untuk membantu institusi kesehatan dalam menginformasikan wabah DBD dan mengendalikan penyebaran nyamuk dan pemberantasan sarang nyamuk.

Teknologi GPS dapat dimanfaatkan melakukan pencarian sarang nyamuk (breeding place) berdasarkan titik kejadian kasus DBD. Yana dan Rahayu menyatakan bahwa breeding place berada dalam radius 100 meter dari kejadian DBD [4]. Karena itu dapat dilakukan upaya pencarian sarang nyamuk jika ada laporan kejadian DBD. Pencarian dapat dilakukan dengan bantuan smartphone yang memiliki fasilitas GPS karena Arsandi dkk. menyatakan bahwa GPS smartphone mempunyai tingkat akurasi sebesar $74 \%$ - 79\% dalam jangkauan jarak sekitar $2.5 \mathrm{~m}$ sampai $3 \mathrm{~m}$ dari tempat sebenarnya [5]. Pernyataan dari [4] dan [5] menjadi salah satu dasar penelitian ini bahwa dimungkinkan untuk mengembangkan aplikasi smartphone untuk mendata keberadaan breeding place dari nyamuk Aedes Aegypti. 
Kemunculan kasus DBD dipengaruhi beberapa faktor antara lain perubahan iklim dan kelembaban nisbi suatu wilayah, jumlah sarang nyamuk Aedes Aegypti misalnya di daerah kumuh, mobilitas penduduk, budaya perilaku sehat dan bersih, serta meningkatnya populasi penduduk di daerah kumuh [7]. Semakin tinggi kepadatan penduduk semakin tinggi peluang terjadi kasus DBD. Nyamuk penyebar DBD lebih menyukai permukiman yang tidak teratur [8]. Kedekatan lokasi ke sungai menjadi faktor meningkatnya kasus DBD karena sungai membawa sampah dan menjadi tempat potensial berkembangnya breeding place [9]. Aedes Aegypti berkembang biak dengan baik pada suhu minimal $10^{\circ} \mathrm{C}$. Kketingian $0-1.000 \mathrm{~m}$ di atas permukaan laut (dpl) dan ketinggian 1.000-1.500 m dpl merupakan rentang ketinggian bagi penyebaran Aedes Aegypti [10].

Teknik buffer digunakan sebagai teknik analisis data dan overlay untuk mengetahui jarak terbang nyamuk dan kedekatan dengan sungai. Analisis untuk menentukan pola sebaran breeding place menggunakan teknik nearest neighbor analysis. Sistem Informasi Geografi (SIG) digunakan dalam menampilkan, menyimpan, mengumpulkan dan menghubungkan data spasial dari fenomena geografis [11]. Perangkat lunak SIG yang semakin mudah digunakan memberikan peluang untuk memvisualisasikan pola spasial dan ruang-waktu untuk data entomologi dan epidemiologi, dan untuk menghasilkan model risiko untuk vektor [12]

Penelitian-penelitian tentang demam berdarah telah banyak dilakukan baik yang berhubungan dengan faktor etiologik seperti faktor host (jenis kelamin, umur, mobilitas). Faktor lingkungan seperti kepadatan nyamuk, kepadatan rumah, angka bebas jentik, curah hujan, perindukan nyamuk. Ada 5 penelitian terdahulu yang digunakan sebagai dasar acuan penelitian. Penelitian pertama oleh Kusuma mengolah data spasial berdasarkan angka bebas jentik dan mendapatkan pola penyebaran DBD [8]. Kedua oleh Helmy di tahun 2015 yang membuat aplikasi mobile untuk pemantauan dini terhadap jentik nyamuk secara online [13]. Ketiga oleh Hendri dkk tahun 2015 yang mengamati perkembangbiakan nyamuk DBD di Kabupaten Ciamis Jawa Barat menggunakan variabel ketinggian wilayah karena penyebaran nyamuk terbatasi dengan suhu [14]. Penelitiannya mengamati perkembangan nyamuk dengan ketinggian 500 di atas permukaan laut (dpl) sampai 1000 dpl dan lebih dari 1000 dpl. Keempat oleh Chang yang yang menggabungkan Google Earth dan SIG untuk pengawasan DBD di Nikaragua dan mengamati perkembangan larva yang digunakan sebagai kontrol DBD sehingga dapat memprioritaskan lingkungan tertentu untuk intervensi control [15]. Kelima oleh Chasanah di tahun 2016 yang melakukan penelitian menggunakan SIG secara deskriptif kuantitatif berdasarkan kedekatan sungai dan lahan pemukiman terhadap titik kasus DBD [16].

Perbedaan penelitian ini dengan dengan penelitian sebelumnya terletak pada lokasi dan metode. Lokasi penelitian ini adalah wilayah Kabupaten Bantul. Sistem di-deploy pada sistem operasi Android. Pemodelan Sistem Informasi Geografis (SIG) dilakukan untuk menghasilkan peta zona risiko insiden DBD untuk mengetahui sejauh mana faktor-faktor berkembangnya breeding place terhadap kedekatan dengan sungai, ketinggian wilayah dan kepadatan permukiman dan bagaimana pola penyebaranmya breeding place di wilayah Kabupaten Bantul. Pada penelitian ini dibuat aplikasi mobile yang memanfaatkan fitur GPS yang digunakan untuk mendapatkan titik lokasi koordinat breeding place, mengetahui pola sebaran dari breeding place. Tujuan penelitian adalah menganalisis hubungan kedekatan sungai, kepadatan penduduk, dan ketinggian wilayah terhadap perkembangan breeding place penyebab DBD di daerah Bantul.

\section{Metode}

\section{a. Desain studi}

Studi dibagi dalam empat tahapan studi, yaitu: Pertama studi diskriptif gambaran mengenai faktor lingkungan dan peningkatan penyakit demam berdarah sejak tahun 2013 sampai dengan tahun 2016 di Kabupaten Bantul. Kedua studi experiment dengan pembuatan program GPS mobile untuk pengambilan titik koordinat breeding place. Ketiga studi survei dengan menangkap lokasi titik breeding place secara acak di seluruh Kabupaten Bantul. Keempat modeling untuk menganalisis spasial breeding place dengan unsur penelitian lain yaitu kedekatan sungai, kepadatan wilayah, dan ketinggian wilayah dalam kasus kerawanan DBD. Tahapan studi, populasi dan analisis yang digunakan dapat dilihat pada Tabel 1 di bawah ini.

Tabel 1. Jenis studi

\begin{tabular}{|c|c|c|}
\hline Studi & Populasi & Analisis \\
\hline Studi Diskriptif & $\begin{array}{l}\text { Kasus DBD sejak } 2013 \\
\text { sampai } 2016 \text { dan faktor- } \\
\text { faktor lingkungan }\end{array}$ & $\begin{array}{l}\text { Diskripsi variabel } \\
\text { tempat dan waktu }\end{array}$ \\
\hline Experiment & $\begin{array}{l}\text { Aplikasi GPS mobile untuk } \\
\text { menangkap titik koordinat } \\
\text { Breeding Place Penyebab } \\
\text { DBD }\end{array}$ & $\begin{array}{l}\text { Analisis tempat } \\
\text { perkembangan jentik } \\
\text { nyamuk DBD }\end{array}$ \\
\hline Studi Survei & $\begin{array}{l}\text { Perkembangbiakan nyamuk } \\
\text { DBD di wilayah Kabupaten } \\
\text { Bantul }\end{array}$ & $\begin{array}{l}\text { Analisis pola sebaran } \\
\text { nyamuk DBD }\end{array}$ \\
\hline Modeling & $\begin{array}{l}\text { Analisa spasial terhadap } \\
\text { kasus DBD di Kabupaten } \\
\text { Bantul }\end{array}$ & Analisis diskriptif \\
\hline
\end{tabular}

\section{b. Lokasi}

Populasi dalam penelitian ini di wilayah area Kabupaten Bantul karena sejak tahun 2013 sampai 2016 terjadi peningkatan kasus DBD. Variabel terikat dalam penelitian ini adalah menggunakan kepadatan permukiman, jarak terhadap sungai dan ketinggian wilayah untuk menentukan tingkat kerawanan penyakit DBD. Sedang Variabel bebasnya adalah menggunakan titik breeding place penyebab DBD.

\section{c. Teknik analisa}

Instrumen penelitian yang digunakan adalah peta wilayah Kabupaten Bantul data breeding place, alat survei jentik, GPS android, dan software SIG. Hasil dari penangkapan koordinat kemudian diolah dengan ArcGIS 10.3. Pendekatan spasial dengan menggunakan analisis dalam SIG Karen dapat diketahui kepadatan penduduk dan jentik nyamuk dalam kasus DBD [10]. Teknik analisis spasial dengan menggunakan Average Nearest Neighbor (ANN), buffering, overlay, Fungsi 3D Analyst, Skor.

\section{d. Peralatan dan data penelitian}

Peralatan penelitian yang digunakan dapat dilihat pada Tabel 2. 
Tabel 2. Alat penelitian

\begin{tabular}{|c|c|c|}
\hline Nama alat & Jenis Alat & Fungsi Alat \\
\hline $\begin{array}{l}\text { HP android } \\
\text { Dengan spesifikasi: } \\
\text { CPU } 2 \text { core } \\
\text { RAM } 2 \text { GB } \\
\text { Memori } 32 \text { GB }\end{array}$ & Hardware & $\begin{array}{l}\text { Menangkap titik } \\
\text { koordinat }\end{array}$ \\
\hline Ms Office & Software & $\begin{array}{l}\text { komputasi pengolahan } \\
\text { data dan pembuatan } \\
\text { laporan }\end{array}$ \\
\hline Laptop & Hardware & $\begin{array}{l}\text { operasional penelitian, } \\
\text { pengolahan data \& } \\
\text { pembuatan laporan, } \\
\text { pembuatan program }\end{array}$ \\
\hline Android Studio & Software & $\begin{array}{l}\text { Membuat program } \\
\text { aplikasi GPS Mobile }\end{array}$ \\
\hline Arc GIS 10.3 & Software & Mengolah data spasial \\
\hline Google Earth & Software & $\begin{array}{l}\text { Menampilkan hasil citra } \\
\text { satelit }\end{array}$ \\
\hline
\end{tabular}

Pada Tabel 3 menunjukkan data penelitian yang meliputi jenis data beserta sumbernya.

Tabel 3. Data penelitian

\begin{tabular}{|c|c|c|}
\hline Nama Data & Jenis Data & Sumber Data \\
\hline Peta Bantul & Gambar Digital & Bappeda Bantul 2010 \\
\hline Data kasus DBD & Tabel & $\begin{array}{l}\text { Profil Kesehatan Kab. } \\
\text { Bantul Dinas Kesehatan } \\
\text { Bantul } 2016\end{array}$ \\
\hline Data Penduduk & $\begin{array}{l}\text { Tabel, Gambar } \\
\text { Peta }\end{array}$ & $\begin{array}{l}\text { RPJMD Kabupaten Bantul } \\
\text { 2011-2015 BPS dan BPN } \\
\text { Kabupaten Bantul }\end{array}$ \\
\hline Data Permukiman & $\begin{array}{l}\text { Tabel, Gambar } \\
\text { Peta }\end{array}$ & $\begin{array}{l}\text { RPJMD Kabupaten Bantul } \\
\text { 2011-2015 BPS dan BPN } \\
\text { Kabupaten Bantul }\end{array}$ \\
\hline Data Sungai & $\begin{array}{l}\text { Tabel, Gambar } \\
\text { Peta }\end{array}$ & $\begin{array}{l}\text { Profil Dinas SDA } \\
\text { Kabupaten Bantul } 2013\end{array}$ \\
\hline $\begin{array}{l}\text { Data Ketinggian } \\
\text { Wilayah }\end{array}$ & $\begin{array}{l}\text { Tabel, Gambar } \\
\text { Peta }\end{array}$ & $\begin{array}{l}\text { BPN Kabupaten Bantul, } \\
\text { Bappeda Bantul } 2010\end{array}$ \\
\hline
\end{tabular}

\section{Hasil}

\section{a. Studi diskriptif}

Hasil studi diskriptif mengenai kecenderungan kasus DBD Kabupaten Bantul semakin meningkat. Kasus DBD mengalami peningkatan yang sangat serius, yaitu pada tahun 2016 sebesar 2442 Gambar 1 dan kasus DBD terbanyak di Kecamatan Kasihan sampai 404 orang dapat dilihat di Gambar 2. Letak geografis Kabupaten Bantul terletak antara $110^{\circ} 12^{\prime} 34^{\prime \prime}-110^{\circ} 31^{\prime} 08^{\prime \prime}$ bujur timur dan $07^{\circ} 44^{\prime} 04^{\prime \prime}-08^{\circ} 00^{\prime} 27^{\prime \prime}$ lintang selatan. Luas wilayah Kabupaten Bantul 508,85 km² dengan topografi lebih dari separuhnya $(60 \%)$ daerah perbukitan yang kurang subur dan dataran rendah 40\%. Daerah landai dan berbukit seluas $89,86 \mathrm{~km}^{2}$ yang membujur dari utara ke selatan $(17,73 \%$ dari seluruh wilayah) terletak wilayah barat. Daerah datar dan landai terletak bagian tengah dan merupakan daerah pertanian yang subur seluas 210.94 $\mathrm{km}^{2}(41,62 \%)$. Luas lahan yang kena aliran sungai 31,8\% dari 50.685,05 Ha. Wilayah permukiman yang terbangun 59,3\% dari 50.685,05 Ha [17]. Daerah aliran sungai di Kabupaten Bantul 2013 dari sungai Progo luas 14.456,36 $\mathrm{Ha}$ dan luas lahan yang dialiri 3462,45 Ha. Sungai Opak luas $24.667,85 \mathrm{Ha}$ dan luas lahan yang dialiri 11964,45 Ha. Sungai Oyo 8474.38 Ha luas 1757,18 Ha dan luas lahan yang dialiri 706,15 Ha. Sedangkan Gumuk Pasir
1645.54. Total keseluruhan luas 50.685,05 dan luas lahan yang dialiri 16133,05 $\mathrm{Ha}$ atau 31\% [18]. Luas berdasar ketinggian wilayah di Kabupaten Bantul 0-7m dpl (dari permukaan laut) sebesar $3228 \mathrm{Ha}(6,3 \%), 7-25 \mathrm{dpl}$ sebesar $8948 \mathrm{Ha}(17 \%)$, 25-100 dpl sebesar 27709 На (54\%) dan 100-500 sebesar $10800 \mathrm{Ha}(21 \%)$ [19]. Kepadatan penduduk wilayah terbangun $30.085 \mathrm{Ha}$ dengan jumlah penduduk 909.812 berarti kepadatan penduduk sebesar 30,24 jiwa per $\mathrm{Ha}$ dari total keseluruhan. Kecamatan Bantul menduduki peringkat pertama 64,02 jiwa per Ha, kedua Kecamatan Kasihan 59,95 jiwa per Ha dan ketiga Kecamatan Banguntapan 53.1 jiwa/Ha [19][20].

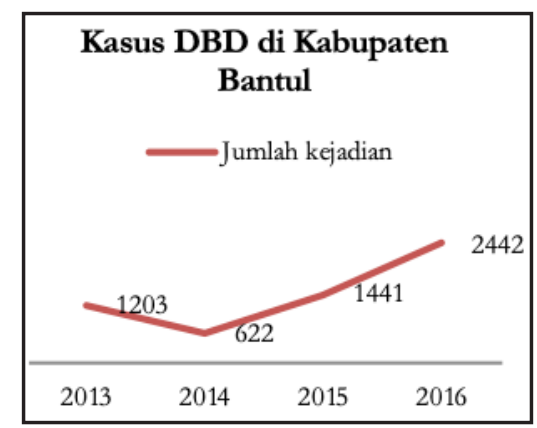

Gambar 1. Grafik peningkatan kasus DBD tahun 20132016

Sumber dinas kesehatan Bantul [21]

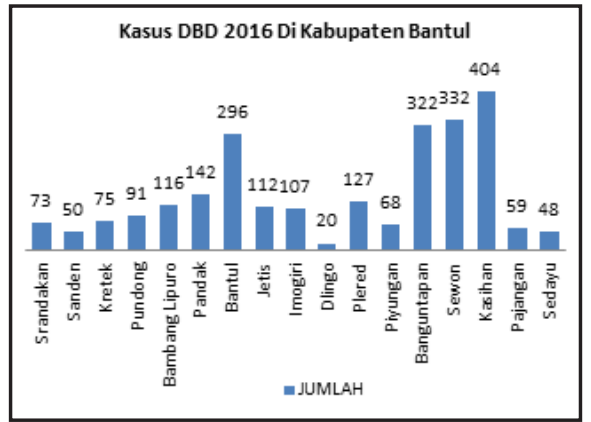

Gambar 2. Grafik jumlah kasus DBD tahun 2016 di Kabupaten Bantul

Sumber dinas kesehatan Bantul [21]

\section{b. Studi experiment dan survey}

Rapid Application Development (RAD) merupakan teknik terstruktur yang digabungkan dengan teknik pengembangan joint application dan teknik prototyping untuk mempercepat pengembangan sistem [22]. Tahapan pengembangan aplikasi GPS mobile dengan metode RAD. Aplikasi ini cukup menggunakan satu tabel, dibuat dengan software Android Studio dan basis data SQLite. Metode RAD mempunyai 3 tahapan utama seperti:

1. Requirements Planning, dalam fase ini untuk mengidentifikasikan tujuan dan kebutuhan aplikasi seperti spesifikasi HP yang bisa digunakan, software pembuatan aplikasi, spesifikasi komputer membuat aplikasi GPS.

2. RAD Design Workshop Fase ini adalah fase untuk merancang desain input layar di HP, struktur basis data, dan desain output.

3. Implementation adalah fase pengembangan desain dengan android studio, evaluasi aplikasi yang telah dibuat dan penerapan langsung di lapangan. 
Tabel 4 tentang desain Basis Data di SQlite cukup tiga field di mana id hanya sebagai nomor dan latitude sebagai sumbu $\mathrm{x}$ dan longitude sebagai sumbu $\mathrm{y}$.

\begin{tabular}{cccc}
\multicolumn{4}{c}{ Tabel 4. Struktur basis data } \\
\hline No & Field & Type & length \\
\hline 1 & id & int & 11 \\
2 & longitude & varchar & 25 \\
3 & latitude & varchar & 25 \\
\hline
\end{tabular}

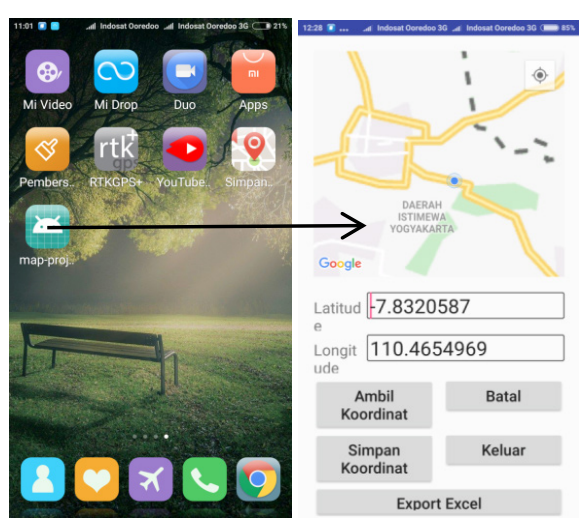

Gambar 3. Tampilan aplikasi GPS mobile

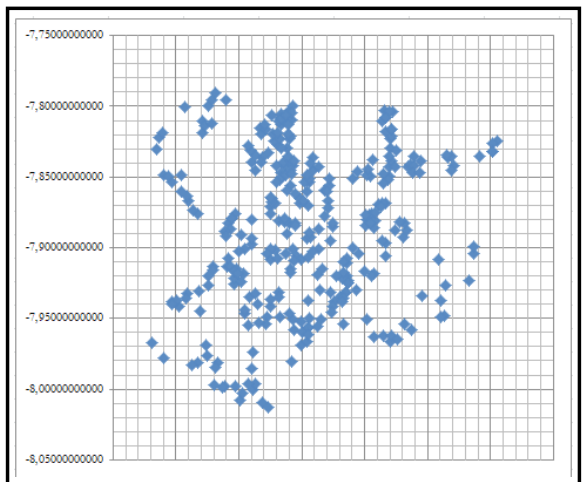

Gambar 4. Hasil studi survei titik koordinat breeding place dari aplikasi GPS mobile ke excel

Hasil koordinat lokasi disimpan dalam koordinat. $\mathrm{db}$ yang bisa di-export menjadi koordinat.xls dan bisa langsung diolah di ArcGIS 10.3. Simpan data (titik, line, atau polygon) tersebut dengan format file *.shp.

Aplikasi GPS mobile ini dalam implementasi digunakan untuk menangkap titik koordinat breeding place. Aplikasi Android dikembangkan menggunakan bahasa pemrograman Java. Java adalah software berorientasi objek berbasis kelas dan digunakan aplikasi web client-server. SDK Android (Kit Pengembangan Perangkat Lunak) menyediakan pustaka API (Application Program Interface) dan alat pengembang yang diperlukan untuk membuat, menguji, dan men-debug aplikasi untuk Android. Data yang dikirim dari aplikasi disimpan SQLite, PHP [23]. Hasil pembuatan aplikasi dapat dilihat pada Gambar 3 dan hasil survei breeding place ada $\mathbf{3 2 4}$ titik yang dilakukan responden di wilayah Kabupaten Bantul dapat dilihat pada Gambar 4

Dari uji coba yang telah dilakukan responden parameter keakuratan dalam aplikasi GPS mobile sangat tergantung pada kedekatan tower Base Transceiver Station (BTS), jenis provider yang digunakan, merk HP Android, cuaca dan kondisi geografis. Kekurangan GPS smartphone dalam penetapan akurasi lokasi tidak begitu berpengaruh karena sudah diuji coba keakuratan memang selisih $2 \mathrm{~m}$ $3 \mathrm{~m}$ terhadap keberadaan breeding place dan kejadian DBD. Hal ini didasari penelitian dari Yuli Yana dan Sri Ratna Rahayu tahun 2017 bahwa radius penderita DBD dengan titik breeding place sejauh $100 \mathrm{~m}$. Hasil koordinat yang dihasilkan dari aplikasi sudah dapat memenuhi membuat peta zona risiko kejadian DBD dan sebagai langkah dini pencegahan DBD.

\section{c. Studi modeling}

Titik breeding place dan sungai dilakukan dengan proses Buffering. Fungsi buffering adalah suatu proses untuk ini menghasilkan data spasial baru yang berbentuk lingkaran apabila berupa titik dan poligon apabila berupa garis yang menjadi masukannya [24].

Wilayah yang memiliki kesamaan karakteritik pada peta tematik dilakukan proses skoring. Skoring dilakukan untuk memberikan nilai tingkatan dari poligon-poligon dari hasil overlay [24].

Proses Buffering titik breeding place menggunakan jarak terbang nyamuk di mana indikasi terbang nyamuk antara $250 \mathrm{~m}-750 \mathrm{~m}$ selebihnya nyamuk sudah tidak punya tenaga lagi selanjutnya dilakukan langkah skoring [8] dapat dilihat di Tabel 5.

Tabel 5. Jarak terbang nyamuk

\begin{tabular}{ccc}
\hline Jarak & skor & status \\
\hline$<250 \mathrm{~m}$ & 3 & Sangat Rawan \\
$250 \mathrm{~m}-750 \mathrm{~m}$ & 2 & rawan \\
$>750 \mathrm{~m}$ & 1 & aman \\
\hline
\end{tabular}

Sebaran breeding place hasil aplikasi GPS mobile di Google Earth dapat dilihat pada Gambar 5 dan sebaran breeding place yang sudah di-buffer dan diberi skor dapat dilihat pada Gambar 6

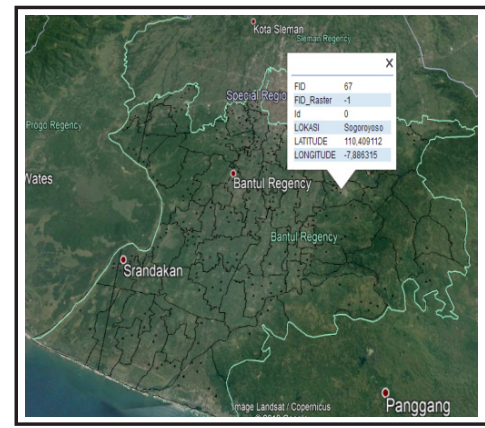

Gambar 5. Peta titik sebaran breeding place dari satelit Google Earth Kabupaten Bantul sebelum di-buffer

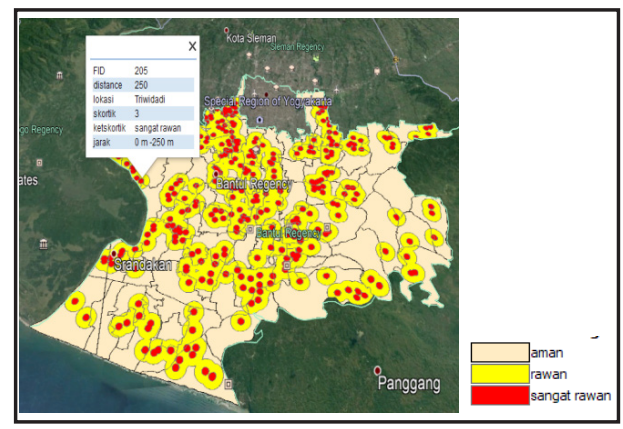

Gambar 6. Peta kasus sebaran breeding place Kabupaten Bantul setelah diskor dan buffer 
Proses Buffering terhadap kedekatan sungai, karena sungai membawa sampah di antaranya dapat menjadi tempat breeding place berkembang biak dengan baik. Wilayah yang dekat dengan sungai menjadi bahan penelitian oleh M.Z Chasanah, 2016 bahwa jarak di bawah $100 \mathrm{~m}$ dari sungai sangat rawan, $100 \mathrm{~m}-1000 \mathrm{~m}$ masih rawan dan diatas $1000 \mathrm{~m}$ bisa dikatakan aman dari DBD selanjutnya dilakukan langkah skoring dapat dilihat pada Tabel 6 .

Tabel 6. Jarak Kedekatan Wilayah dengan Sungai

\begin{tabular}{ccc}
\hline Jarak & skor & status \\
\hline$<100 \mathrm{~m}$ & 3 & Sangat Rawan \\
$100 \mathrm{~m}-1000 \mathrm{~m}$ & 2 & rawan \\
$>1000 \mathrm{~m}$ & 1 & aman \\
\hline
\end{tabular}

Gambar sungai dan anak sungai wilayah Kabupaten Bantul di Google Earth dapat dilihat pada gambar 7 dan sungai dan anak sungai yang sudah di-buffer dan diberi skor dapat dilihat pada Gambar 8

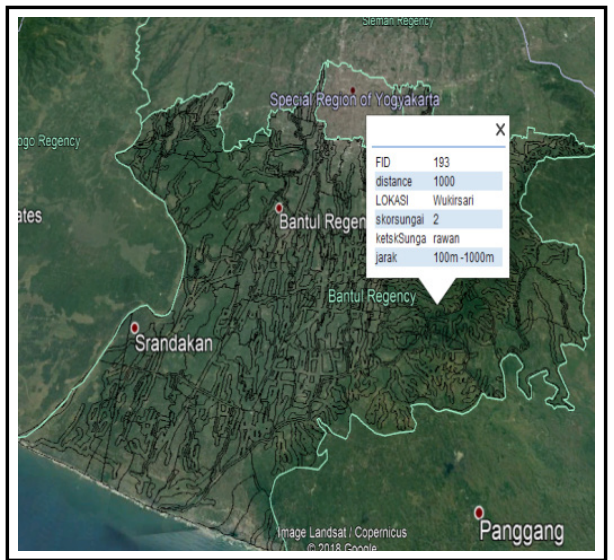

Gambar 7. Peta dilihat dari satelit Google Earth wilayah aliran sungai Kabupaten Bantul

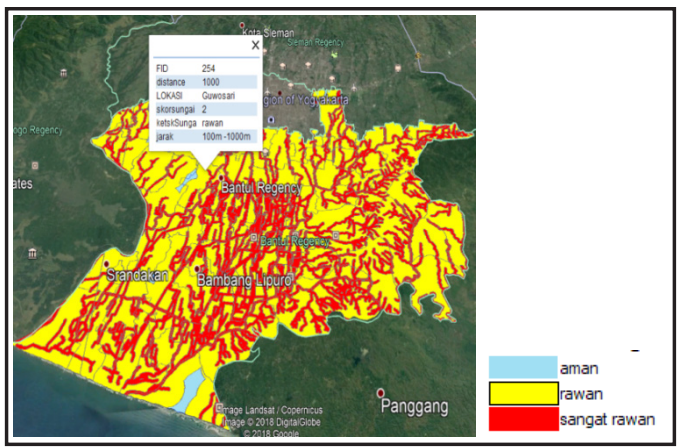

Gambar 8. Peta kasus wilayah aliran sungai dan anak sungai Kabupaten Bantul setelah diskor dan buffer

Kepadatan permukiman dapat diketahui dengan cara menghitung antara luas atap rumah mukim dibagi dengan total luas blok mukim kemudian dikali seratus persen. Permukiman padat sangat berpengaruh terhadap perkembangbiakan nyamuk DBD. Area yang tertinggi adalah area dengan tingkat kepadatan penduduk tinggi atau daerah yang sangat padat penduduknya, yaitu di atas $60 \%$ (sangat rawan) dan tingkat kepadatan penduduk terendah di bawah 40\% (aman) selanjutnya dilakukan langkah skoring [16] dapat dilihat pada Tabel 7.
Tabel 7. Kepadatan permukiman

\begin{tabular}{ccc}
\hline Jarak & skor & status \\
\hline$<40 \%$ & 1 & aman \\
$40 \%-60 \%$ & 2 & rawan \\
$>60 \%$ & 3 & Sangat Rawan \\
\hline
\end{tabular}

Gambar kepadatan penduduk wilayah Kabupaten Bantul di Google Earth dapat dilihat pada Gambar 9 dan kepadatan yang sudah dihitung dengan ArcGIS 10.3 dan diberi skor dapat dilihat pada Gambar 10

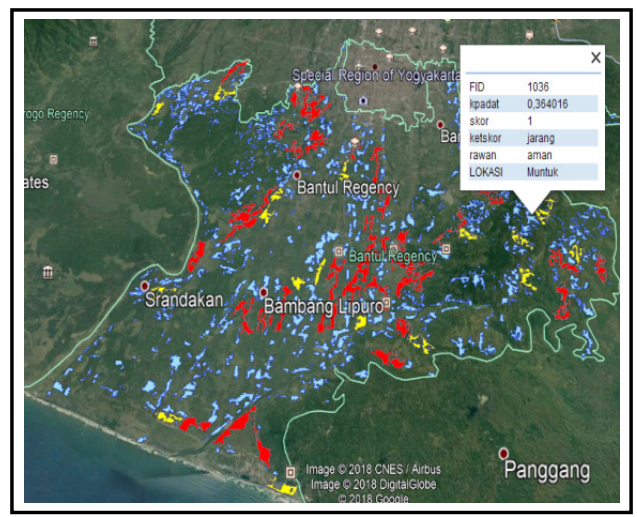

Gambar 9. Peta kasus kepadatan penduduk Kabupaten Bantul dilihat dari satelit Google Earth

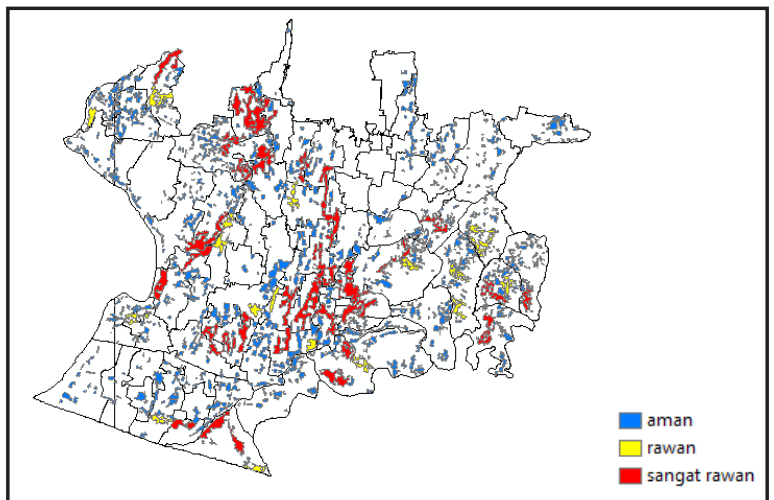

Gambar 10. Peta Kasus Kepadatan Penduduk Kabupaten Bantul Setelah Diskor

Menampilkan data spasial dalam ruang tiga dimensi menggunakan fungsi 3D Analyst. Fungsi interpolasi banyak digunakan untuk fungsi analisis spasial [24]. Kontur dari wilayah Bantul menggunakan 3D Analyst untuk mendapatkan data spasial ketinggian. Interval ketinggian Kabupaten Bantul selanjutnya dilakukan langkah skoring. Dapat dilihat pada Tabel 8

Tabel 8 Ketinggian wilayah Kabupaten Bantul

\begin{tabular}{llll}
\hline Kelas & Interval & Diskripsi & Skor \\
\hline 1 & $0 \mathrm{~m}-7 \mathrm{~m}$ & datar & 4 \\
2 & $7 \mathrm{~m}-25 \mathrm{~m}$ & sedang & 3 \\
3 & $25 \mathrm{~m}-100 \mathrm{~m}$ & tingg1 & 2 \\
4 & $>100 \mathrm{~m}$ & Sangat tinggi & 1 \\
\hline Sumber BPN & Bantul &
\end{tabular}

Gambar kontur wilayah Kabupaten Bantul yang sudah diproses dengan 3D Analyst. Dapat dilihat pada Gambar 11 dan wilayah ketinggian Kabupaten Bantul yang sudah diberi skor dapat dilihat pada Gambar 12 


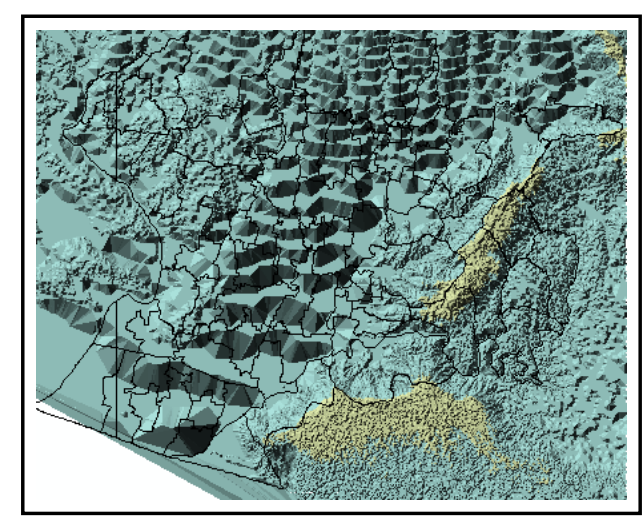

Gambar 11. Peta kontur hasil 3D Analyst wilayah Kabupaten Bantul

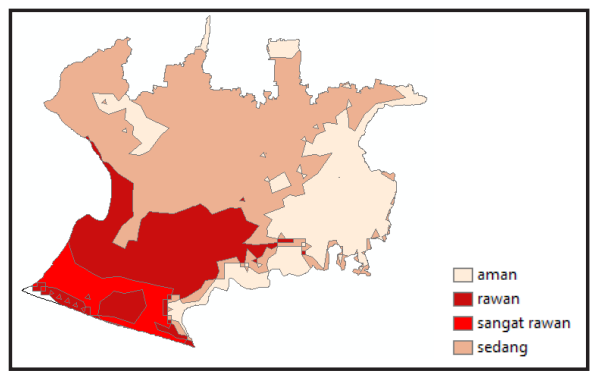

Gambar 12. Peta kasus ketingggian wilayah Kabupaten Bantul setelah di skor

\section{Diskusi}

Analisis kasus penyebaran titik breeding place dengan menggunakan Average Nearest Neighbor (ANN). Ukuran signifikansi statistik yang menunjukkan distribusi data acak adalah Z-score dan p-value. Nilai p-value adalah probabilitas bahwa pola spasial yang diamati diciptakan oleh beberapa proses acak. Ketika p-value sangat kecil, artinya sangat tidak mungkin (probabilitas kecil) bahwa pola spasial yang diamati adalah hasil dari proses acak, sehingga menolak hipotesis nol. Z-score adalah standar deviasi. Z-score dan p-value dikaitkan dengan distribusi normal standar. [25]. Pola kerumunan breeding place dapat dilihat pada Gambar 13.

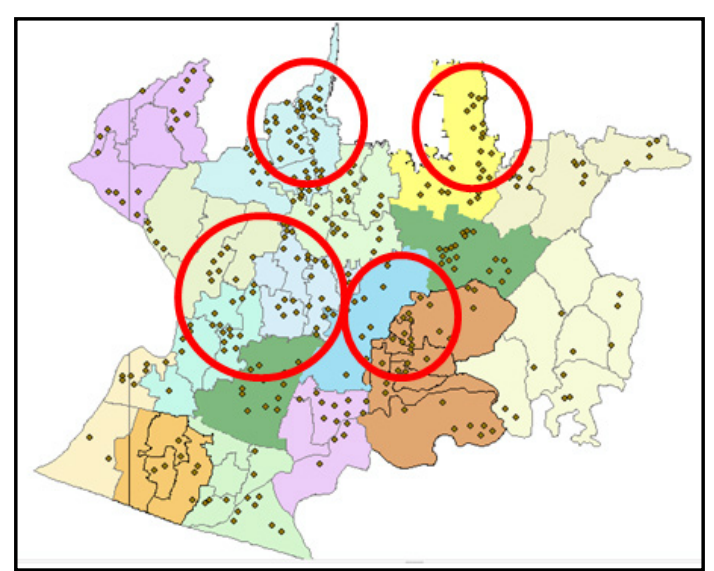

Gambar 13 Distribusi spasial Breeding Place di wilayah Bantul
Hasil analisis ANN menggunakan ArcGis 10.3, diperoleh bahwa sebaran breeding place memiliki rasio sebesar 0,690 dengan Z-score sebesar -10,663 <-2.58 $P$-value 0,000 dengan tingkat kepercayaan dalah 95 persen. Jarak rata-rata antar breeding place sebesar 512,18m. Pola sebaran Breding Place yang terjadi di wilayah Kabupaten Bantul bersifat berkerumun dan rasio tersebut berada dalam parameter yang menunjukkan pola spatial clustered dapat dilihat pada Tabel 9

Tabel 9.Hasil perhitungan average nearest neighbor

\begin{tabular}{cc}
\hline Average Nearest Neighbor Summary \\
\hline Observed Mean Distance & 512,180 \\
Nearest Neighbor Ratio & 0,690 \\
z-score & $-10,663$ \\
p-value & 0,000 \\
\hline
\end{tabular}

Data spasial baru minimal dua data spasial yang menjadi masukannya dihasilkan dari fungsi overlay [24]. Overlay antara breeding place dengan wilayah ketinggian Kabupaten Bantul untuk mengetahui peta zona risiko dapat dilihat pada Gambar 15 dan hasil spasial pengaruh perkembangbiakan breeding place dengan ketinggian wilayah dapat dilihat pada Tabel 10.

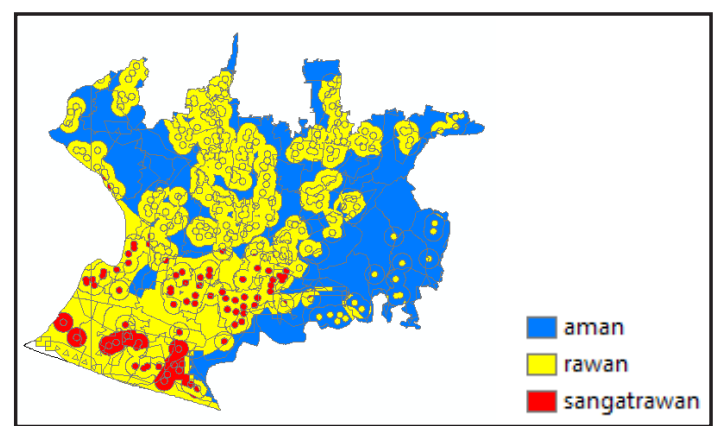

Gambar 15. Overlay ketinggian dengan breeding plac

Tabel 10. Overlay ketinggian wilayah dengan breeding place

\begin{tabular}{ccl}
\hline Status & Prosentase & Keterangan \\
\hline aman & $40 \%$ & aman \\
rawan & $52 \%$ & $\square$ rawan \\
sangat rawan & $8 \%$ & $\square$ sangatrawan \\
\hline
\end{tabular}

Hasil overlay antara breeding place yang sudah di buffer dengan ketinggian wilayah di Kabupaten Bantul menghasilkan peta zona risiko yaitu daerah aman $40 \%$, rawan $52 \%$ dan sangat rawan $8 \%$. Hal ini pernah dilakukan penelitian oleh Joni Hendri dkk tahun 2015 perkembangbiakan nyamuk DBD masih cukup baik pada ketinggian di atas $1.000 \mathrm{~m}$ dpl dan lokasi penelitiannya berada pada ketinggian di atas $500 \mathrm{~m}$ dpl. Hal ini disebabkan terjadinya pergeseran ekosistem yang disertai degradasi lingkungan sehingga memperluas ruang bagi Aedes aegyti untuk berkembang biak sehingga daerah pegunungan suhunya relatif rendah sekarang mulai meningkat [26].

Overlay antara breeding place dengan wilayah kedekatan dengan sungai di Kabupaten Bantul untuk mengetahui peta zona risiko dapat dilihat pada Gambar 16 dan hasil spasial pengaruh perkembangbiakan breeding place dengan kedekatan dengan sungai dapat dilihat pada Tabel 11. 


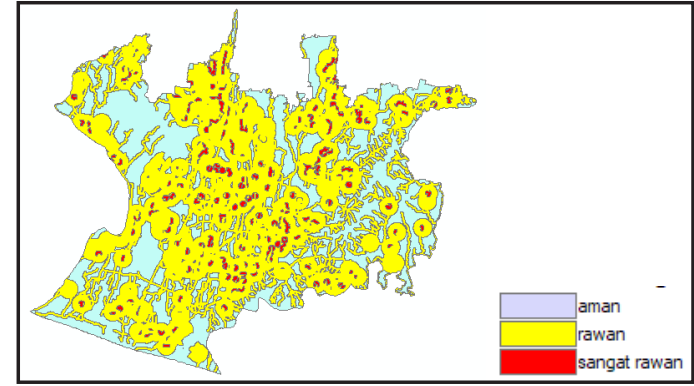

Gambar 16. Overlay antara sungai dan breeding place

Tabel 11. Overlay antara sungai dan breeding place

\begin{tabular}{ccc}
\hline Status & Prosentase & Keterangan \\
\hline aman & $21 \%$ & aman \\
rawan & $66 \%$ & rawan \\
& $13 \%$ & sangat rawan \\
sangat rawan & $13 \%$ \\
\hline
\end{tabular}

Hasil overlay antara buffer breeding place dengan wilayah sekitar buffer sungai di Kabupaten Bantul menghasilkan peta zona risiko yaitu daerah aman $21 \%$, rawan $66 \%$ dan sangat rawan $13 \%$. Hal ini pernah dilakukan penelitian oleh M.Z. Chasanah 2016 tanpa breeding place sebagai overlay dengan kedekatan sungai menghasilkan kerentanan $11,37 \%$ sebagai daerah rawan DBD. Kondisi ini jauh berbeda karena tidak disertai variabel breeding place terhadap sungai.

Overlay antara breeding place dengan wilayah kepadatan permukiman di Kabupaten Bantul untuk mengetahui peta zona risiko dapat dilihat pada Gambar 17 dan hasil spasial pengaruh perkembangbiakan breeding place dengan kepadatan permukiman dapat dilihat pada Tabel 12.

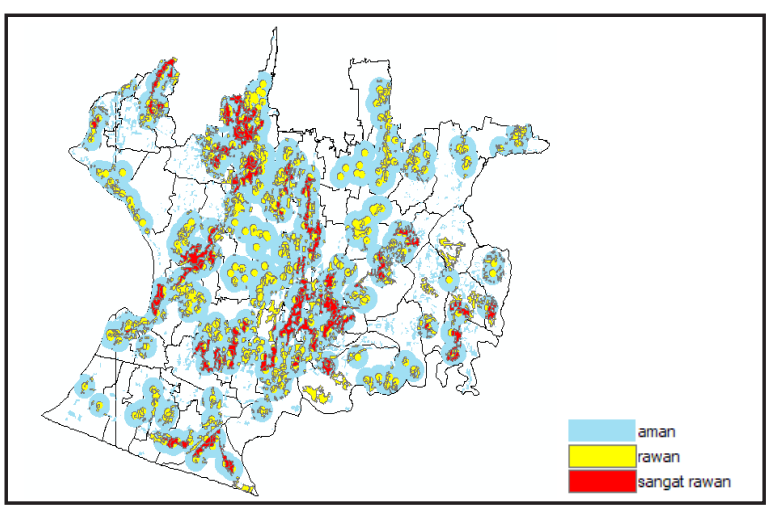

Gambar 17. Overlay kepadatan permukiman dan breeding place

Tabel 12. Overlay kepadatan permukiman dan breeding place

\begin{tabular}{ccc}
\hline Status & Prosentase & Keterangan \\
\hline Aman & $38 \%$ & aman \\
Rawan & $56 \%$ & rawan \\
sangat rawan & $6 \%$ & sangat rawan \\
\hline
\end{tabular}

Hasil overlay antara breeding place yang sudah di-buffer dengan kepadatan permukiman di Kabupaten Bantul menghasilkan peta zona risiko yaitu daerah aman 38\%, rawan $56 \%$, dan sangat rawan $6 \%$. Hal ini sesuai penelitian yang dilakukan oleh M.Z. Chasanah pada tahun 2016 tanpa breeding place bahwa kepadatan sangat berpengaruh terhadap kasus DBD dengan nilai kerentanan 19,54\%.
Ketinggian wilayah, kedekatan dengan sungai, kepadatan permukiman dan breeding place kemudian dioverlay untuk mengetahui peta zona kerawanan terhadap DBD di wilayah Kabupaten Bantul dapat dilihat pada Gambar 18 dan hasil spasial data dilihat pada Tabel 13

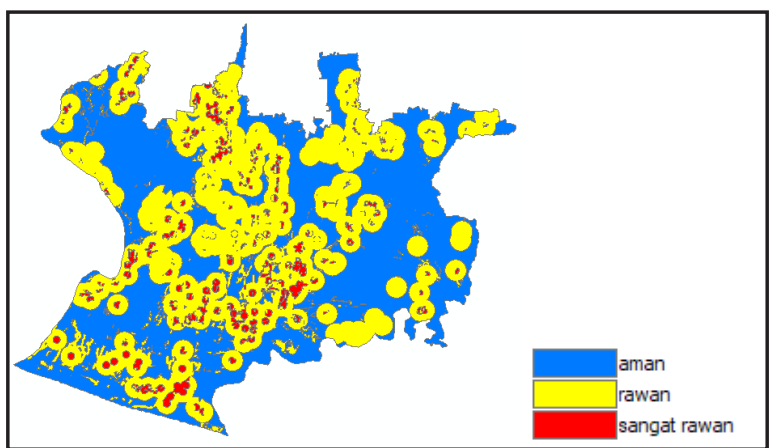

Gambar 18. Overlay kepadatan permukiman, kedekatan dengan sungai dan ketinggian wilayah dengan Breeding Place

Tabel 13. Overlay kepadatan permukiman, kedekatan dengan sungai dan ketinggian wilayah dengan Breeding place

\begin{tabular}{ccc}
\hline Status & Prosentase & Keterangan \\
\hline aman & $25 \%$ & aman \\
rawan & $64 \%$ & rawan \\
sangat rawan & $11 \%$ & sangat rawan \\
\hline
\end{tabular}

Hasil overlay antara breeding place yang sudah dibuffer dengan ketinggian wilayah, kedekatan sungai dan kepadatan penduduk di Kabupaten Bantul menghasilkan peta zona risiko, yaitu daerah aman $25 \%$, rawan $64 \%$, dan sangat rawan $11 \%$. Penentuan variabel yang paling berpengaruh terhadap kerawanan penyakit DBD di wilayah Kabupaten Bantul dapat dilihat pada Gambar 19.

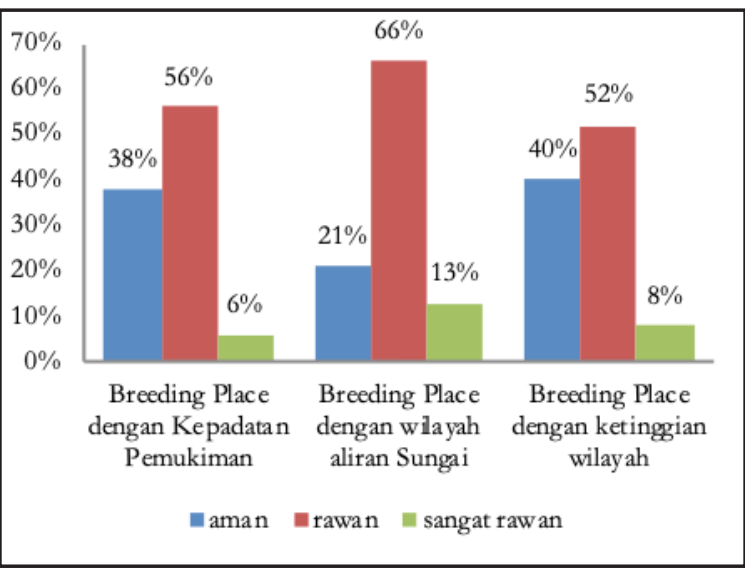

Gambar 19 Grafik parameter yang berpengaruh terhadap perkembangbiakan Breeding Place di wilayah

\section{Kabupaten Bantul}

Gambar 19 menunjukkan bahwa breeding place penyebab terjadinya DBD dengan kedekatan sungai sangat berpengaruh dengan tingkat rawan $66 \%$. Breeding place dengan kepadatan penduduk sebesar 56\% dan breeding place dengan ketinggian wilayah sebesar $52 \%$.

Pada tanggal 24 Januari 2019 diadakan sosialisasi instalasi dan penggunaan aplikasi kepada 68 kader Puskesmas dalam acara program pelatihan survei jentik di 
Puskesmas Piyungan, Desa Sitimulyo, Piyungan, Bantul. Hampir 90\% kader dapat menggunakann aplikasi dengan baik dan 10\% gagal. Kegagalan pengguna disebabkan beberapa faktor seperti usia pengguna, memori HP terbatas, kemampuan pengoperasian smartphone yang terbatas dan sistem operasi smartphone bukan Android. Aplikasi yang dihasilkan memiliki kelebihan dan kekurangan. Kelebihannya adalah:

a. Aplikasi GPS mobile mudah dipahami karena fitur dibuat semudah mungkin yang disesuaikan tingkat pengetahuan jumantik dan mempermudah para user dalam mengirim data via online.

b. Data breeding place ditampilkan dalam bentuk grafik dan data spasial.

c. Informasi breeding place terhadap kasus DBD dapat di-update sesuai perkembangan setiap tahunnya.

d. User dapat mengetahui sebaran risiko DBD di tiap kecamatan secara kenampakan kegeografisan, jadi tidak hanya berupa data tulisan.

Kekurangan aplikasi ini antara lain:

a. Tingkat akurasi aplikasi GPS mobile sangat dipengaruhi oleh kedekatan tower Base Transceiver Station (BTS), jenis provider yang digunakan, merk HP Android, cuaca, dan kondisi geografis.

b. Visualisasi data memerlukan aplikasi lain karena file berbentuk excel. Tidak semua pengguna menguasai pengoperasian excel.

c. Sistem operasi harus Android, sistem operasi lain belum didukung.

d. Space memori minimal $200 \mathrm{MB}$ saat instalasi, dirasa cukup berat untuk sebagian perangkat.

\section{Kesimpulan}

Berdasarkan penelitian yang telah dilakukan maka dapat disimpulkan Kabupaten Bantul memiliki area rawan kasus DBD sebesar 64\%, sangat rawan sebesar $11 \%$ dan aman dari DBD 25\% dari luas wilayah. Data dari aplikasi GPS mobile berisi titik breeding place telah diproses dengan Average Nearest Neighbor menggunakan ArcGIS 10.3 menghasilkan nilai ANN sebesar $0,690330<1$ yang berarti pola penyebaran nyamuk DBD bersifat berkerumun dan nilai $z$-score $-10,663560<-2.58$ artinya ada pola spasial clustered. Pertumbuhan breeding place di wilayah Kabupaten Bantul sangat erat hubungannya dengan wilayah padat permukiman, ketinggian wilayah dan yang paling berpengaruh adalah kedekatan dengan sungai sebesar 66\% dari wilayah Kabupaten Bantul.

Hasil sosialisasi menunjukkan bahwa aplikasi GPS mobile dapat membantu institusi kesehatan dalam mengambil tindakan pencegahan DBD secara dini karena informasi berupa file excel dapat ditransfer secara online lewat WhatsApp. Masyarakat dapat mewujudkan program pemerintah yaitu Satu Rumah Satu Jumantik.

\section{Ucapan Terima Kasih}

Universitas Ahmad Dahlan Yogyakarta yang memfasilitasi penggunaan laboratorium komputer mobile di MTI dan perpustakaan dalam mendukung dan membantu penelitian ini.

\section{Daftar Pustaka}

[1] Tyrsa C. N. Monintja, "Hubungan Antara Karakteristik Individu, Pengetahuan, dan Sikap dengan Tindakan PSN DBD Masyarakat Kelurahan Malalayang I Kecamatan Malalayang Kota Manado," JIKMU, vol. 5, No. 2b, pp 503519, 2015.

[2] P.Widyorini, N.E. Wahyuningsih dan R. Murwani, "Faktor Keberadaan breeding place dengan Kejadian Demam Berdarah Dengue di Semarang," Jurnal Kesehatan Masyarakat, vol. 4, no.5, pp. 94-99, 2016.

[3] DinKes, Petunjuk Teknis Implementasi PSN $3 M$ Plus dengan Gerakan 1 Rumab 1 Jumantik, Edisi I, Jakarta. 2016.

[4] Yuli Yana dan Sri Ratna Rahayu, "Analisis Spasial Faktor Lingkungan dan Distribusi Kasus Demam Berdarah Dengue," Higeia, vol. 1, no. 32017.

[5] Brisma Meihar Arsandi., Triyogatama Wahyu Widodo,, dan Faizah, "Purwarupa Sistem Pembuka Pintu Cerdas Menggunakan Perceptron Berdasarkan Prediksi Kedatangan Pemilik," IJEIS, vol. 7, no. 1, pp. 83-92, 2017.

[6] Sathyamorthy, D., Shafii, S., Amin, Z. F. M., Jusoh, A., dan Ali, S. Z. "Evaluating the TradeOff between Global Positioning System (GPS) Accuracy and Power Saving from Reduction of Number of GPS Receiver Channels," Applied Geomatics, vol 8, no. 2, pp. 67-75, 2016

[7] S.Soegeng, Demam Berdarah Dengue, Edisi kedua. Surabaya, Airlangga University Press, 2006.

[8] A.P. Kusuma dan D.M. Sukendra, "Analisis Spasial Kejadian Demam Berdarah Dengue Berdasarkan Angka Bebas Jentik," Jurnal Ilmiah Permas: Jurnal Ilmiah STIKES Kendal, vol. 7, no. 2, pp. 37-44, 2017.

[9] A.P. Wijaya dan A. Sukmono, "Estimasi Tingkat Kerawanan Demam Berdarah Dengue Berbasis Informasi Geospasial," Jurnal Geografi, vol. 14, no.1, 2017.

[10] WHO, "Panduan Lengkap Pencegahan Dan Pengendalian Dengue Dan Demam Berdarah Dengue," (alih bahasa Palupi Widyastuti), Regional Office fo South Easth Asia Region World Health Organization, New Delhi Jakarta: Penerbit Buku Kedokteran EGC, 2001.

[11] Achmadi dan U. Fahmi, Manajemen Penyakit Berbasis Wilayah. Rajawali Press, Jakarta, 2012.

[12] M. Palaniyandi, "Web Mapping GIS: GPS under the GIS Umbrella for Aedes Species Dengue and Chikungunya Vector Mosquito Surveillance and Control," IJMR, vol 1, no. 3, pp. 18-25, 2014.

[13] Helmy, S.Widodo dan Y.I. Permatasari1, "Sistem Informasi dan Pemantauan Dini terhadap JentikJentik Nyamuk Secara Online di Kelurahan Bulusan, Kecamatan Tembalang, Semarang," TELE, vol. 13, no. 1, pp. 38-44, 2015. 
[14] Joni Hendri., Roy Nusa Rahagus Edo Santya., dan Heni Prasetyowatil, "Distribusi dan Kepadatan Vektor Demam Berdarah Dengue (Dbd) Berdasarkan Ketinggian Tempat di Kabupaten Ciamis Jawa Barat," Jurnal Ekologi Kesehatan, vol. 14, no. 1, pp. $17-28,2015$.

[15] A.Y Chang, "Combining Google Earth And GIS Mapping Technologies in A Dengue Surveillance System for Developing Countries," International Journal of Health Geographics, Vol. 8, no. 49, 2009.

[16] M.Z. Chasanah, "Analisis Tingkat Kerawanan Penyakit Demam Berdarah Dengue (Dbd) di Kecamatan Gondokusuman Kota Yogyakarta dengan Berbantuan Sistem Informasi Geografis," e Journal UNY, 2016.

[17] Bappeda Bantul 2010, Peta Administrasi Kabupaten Bantul.

[18] Profil Dinas SDA Kabupaten Bantul 2013.

[19] RPJMD Kabupaten Bantul 2011-2015, BPN Kabupaten Bantul.

[20] RPJMD Kabupaten Bantul 2011-2015, BPS Kabupaten Bantul.
[21] Profil Kesehatan Kabupaten Bantul Dinas Kesehatan Bantul 2016.

[22] Whien, J.L. \& Bentley, L.D, System Analysis \& Design Methods, Sixth Edition. New York: Mc.Graw-Hill, 2004.

[23] E.Reddy, S.Kumar, N. Rollings, dan R.Chandra, "Mobile Application for Dengue Fever Monitoring and Tracking via GPS: Case Study for Fiji," arXiv, vol. 1503.00814, No. 1, 2015.

[24] B. Raharjo dan M. Ikhsan, Belajar ArcGIS Desktop 10.2/10.3, Geosiana Press .edisi ke 2, Banjar Baru, 2015.

[25] Mohd Hazrin., Helen Guat Hiong., Nadzri Jai1., Norzawati Yeop., Muhammad Hatta., Faizah Paiwai., S. Joanita., dan W. Othman, "Spatial Distribution of Dengue Incidence: A Case Study in Putrajaya," Journal of Geographic Information System, vol. 8, pp. 89-97, 2016.

[26] Jusniar Ariati dan Athena Anwar, "Model Prediksi Kejadian Demam Berdarah Dengue (Dbd) Berdasarkan Faktor Iklim di Kota Bogor, Jawa Barat," Bul. Penelit. Kesehat, vol. 42, no. 4, pp. 249256, 2014. 